\title{
Perforated Duodenal Uleer in a Gase of Situs Inversus Totalis in an Elderly Woman: A Rare Presentation
}

\section{JER}

Biswajit Barai, Sabuj Bala, Partha Chakraborty, Arnab Mandal, Ramkrishna Mandal

Department of General Surgery, B.S. Medical College, Bankura, West Bengal, India.

\section{Abstract:}

Situs inversus is a rare congenital anomaly where the intra-abdominal viscus are reversed or mirrored from their normal position. When associated with dextrocardia it is termed as situs inversus totalis. Though patients are asymptomatic, when presented with any pathology, the transpositioned viscus poses diagnostic difficulty, sometimes catastrophe. First reported in 1986, we in this article perhaps are reporting the third case of situs inversus totalis that presented with peptic perforation.

Key words: Dextrocardia, Heterotaxy Syndrome, Humans, Situs Inversus, Viscera.

\section{Introduction}

Situs inversus (also called situs transversus) is a congenital condition in which all the intrathoracic and intraabdominal visceral organs are reversed or mirrored from their normal embryogenic anatomical position [1-4]. Dextrocardia is an abnormal congenital malpositioning of the heart where the heart, instead of forming on the left side of fetal thoracic cavity, flips over and forms on the right side. In cases of 'situs inversus totalis' or 'mirror image dextrocardia' the heart is on the right side of the midline while the liver and gall bladder are on the left side along with a 'mirror image' of the normal bowel, caused by a clockwise rotation of the viscera's in early embryonic life [2].

It is an uncommon anomaly with incidence of $0.01 \%$ the exact etiology is unknown though mutations in the DNAH1 1 (axonemal heary chain dynein type 11) gene along with an autosomal recessive pattern of inheritance has been speculated [5]. In our extensive search through all the available literatures in the internet, very few cases of situs inversus with dextrocardia presenting as perforated duodenal ulcers have been reported. Therefore the rarity of this clinical condition prompts us to publish this case report.

\section{Case Report}

A 62 years old non-smoker, non-alcoholic woman was admitted in our surgical ward with sudden onset severe epigastric and left hypochondrial pain for last 8 hours. She also complained of nausea and two episodes of vomiting; she also gave history of recurrent episodes of epigastric pain in the past. On examination, she had a pulse rate of 108 beats

Corresponding Author: Dr. Biswajit Barai

Email: drbiswamck@gmail.com

Received: February 7, 2016 | Accepted: April 13, 2016 | Published Online: May 20, 2016

This is an Open Access article distributed under the terms of the Creative Commons Attribution License (creativecommons.org/licenses/by/3.0)

Conflict of interest: None declared | Source of funding: Nil | DOl: http://dx.doi.org/10.17659/01.2016.0054 
per minute, blood pressure was $124 / 80 \mathrm{~mm} \mathrm{Hg}$. Her tongue was coated and she was afebrile. On abdominal examination, she revealed guarding and rigidity in epigastrium and left hypochondrium. Her laboratory reports showed a serum hemoglobin level of $9.2 \mathrm{gm} \%$ and a white cell count of 11,400 per cu. $\mathrm{mm}$ with neutrophilia (88\%). Platelet count was $2,05,000$ per cu. $\mathrm{mm}$ with no abnormal cells on peripheral blood smear. Her serum amylase level was slightly raised above the normal upper limit but lipase was within normal reference range. Other biochemical tests and electrolytes were normal.

The X-ray abdomen in erect posture showed fundic gas shadow under right dome of diaphragm with free gas under both domes of diaphragm [Fig.1]. The chest X-ray showed dextrocardia. An electrocardiogram was performed which was diagnostic of dextrocardia without any other abnormal findings. A clinical diagnosis of hollow viscus perforation, probably perforated duodenal ulcer in a case of dextrocardia with situs inversus was made. A subsequently performed ultrasonography confirmed the suspicion of situs inversus showing the presence of liver and gall bladder on left side without any pathology [Fig.2]. The spleen was present on the right side with normal echotexture.

After proper resuscitation with intravenous fluids, antibiotics, analgesics, proton pump inhibitors and naso-gastric suction, the patient underwent exploratory laparotomy; on exploration the provisional diagnosis of duodenal ulcer perforation was confirmed. There was a perforation of approximately $4 \mathrm{~mm}$ diameter in the anterior wall of first part of duodenum [Fig.3]. The fundus of the stomach was on right side along with the first part of duodenum which was on the left of the midline lying in left hypochondrium. The liver with gall bladder was on left side and spleen on right side. On further exploration, the rest of abdomen showed typical features of situs inversus totalis i.e. the caecum with

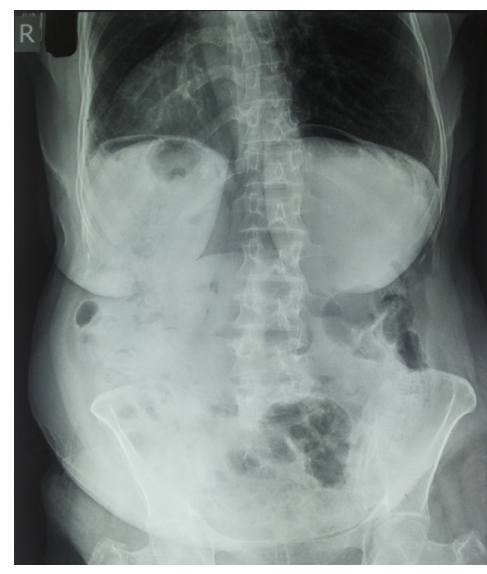

Fig. 1: Straight X-ray abdomen showing free gas under both domes of diaphragm with fundic gas shadow on right side.

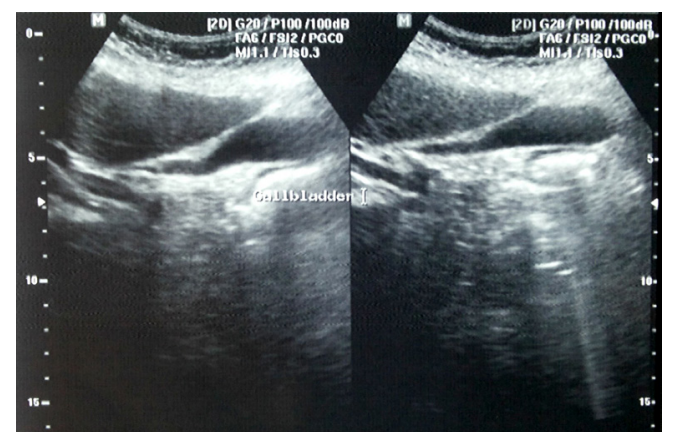

Fig.2: Ultrasound whole abdomen showing liver and gallbladder on left side.

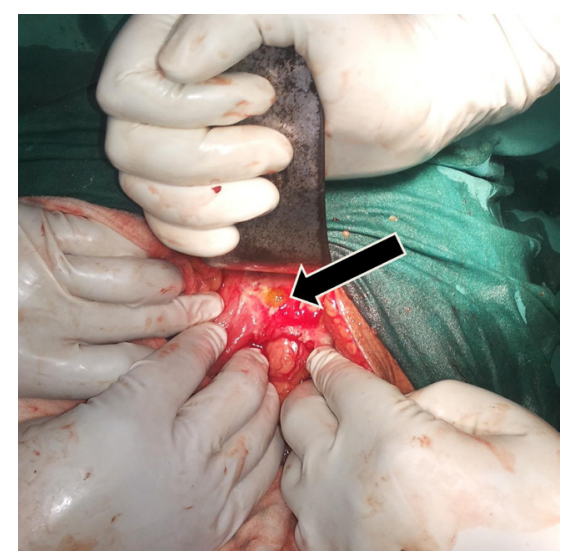

Fig.3: Intraoperative picture of peptic perforation. 
appendix on left iliac fossa and sigmoid colon on right side [Fig.4].

The duodenal perforation was closed with Graham's omental patch secured with absorbable polyglycolic acid sutures. An incidental appendectomy was performed to avoid future diagnostic problems. After thorough peritoneal lavage the abdomen was closed in layers. The patient had an uneventful post-operative recovery.

\section{Discussion}

In the year 1643, Marco Severino described dextrocardia and nearly after a century, Matthew Baillie first described the description of situs inversus as a complete mirror-image reversal of abdominal and thoracic organs. The word situs denotes the position viscera's and cardiac atria. 'Situs solitus' being the normal position and situs inversus is the mirror image of it [6]. Situs inversus can be classified in two groups based on the direction of cardiac apex at birth. The first one is situs inversus with levocardia and the other one being situs inversus with dextrocardia [7]. Situs inversus with dextrocardia is also known as situs inversus totalis. There are also reported cases of situs ambiguous or heterotaxy, where liver may be in midline, absent spleen or multiple spleen and malrotated bowel leading to diagnostic confusion [8].

A large number of associated congenital abnormalities are reported with situs inversus [2]. Among them cardiac anomalies like transposition of great vessels and congenital heart diseases are frequent [9]. Nearly 20\% patients of situs inversus have Kartagener syndrome [10]. However, in our patient there was no cardiac abnormality, left isomerism, polysplenia, asplenia or associated heterotaxy. No significant family history was also present.

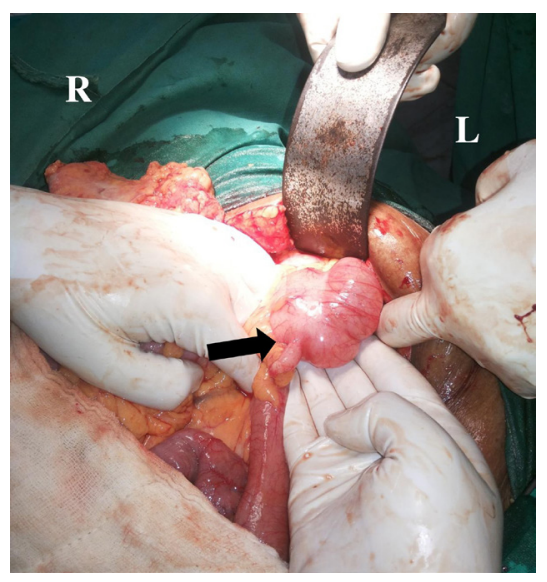

Fig.4: Intraoperative picture showing caecum with appendix on left iliac fossa.

Situs inversus usually remains undiagnosed, unless found incidentally while performing investigations for other ailments. It is important to diagnose this condition pre-operatively in cases of diagnostic dilemma arising from unusually located abdominal visceral pathology as well as to determine the site of proper surgical incision for management. In our case as diagnosis of situs inversus was made preoperatively, an exploratory laparotomy was performed through upper midline incision.

To diagnose situs inversus, different modalities such as electrocardiogram, echocardiogram, ultrasonography, computed tomography (CT) scans, radiographic studies can be used [11]. In our patient diagnosis was made by straight $X$-ray abdomen in erect posture and chest X-ray and corroborated by ultrasonography of whole abdomen and electrocardiography. There have been isolated reports of situs inversus associated with sudden death [12], cardiac anomalies [13], peptic ulcer [3], acute cholecystitis and cholelithiasis [14], acute appendicitis [15], intestinal obstruction [16] and amoebic liver abscess [17]. To the best of our knowledge, this may be the third case report in the literature of a patient with situs inversus totalis 
presenting with perforated duodenal ulcer. Gandhi et al. [3] reported the first case of perforated duodenal ulcer with situs inversus in 1986 and Tayeb et al. [18] reported the second one in 2011.

\section{Conclusion}

Failure to recognize situs inversus before any radiologic procedure or surgical intervention may lead to incorrect placement of incision or intervention on the incorrect side of the patient. Attention to the proper side labeling of images may prevent fatal mistakes in diagnosis and/or interventions.

\section{References}

1. Blegen HM. Surgery in situs inversus. Ann Surg. 1949; 1 29:244-259.

2. Lee SE, Kim HY, Jung SE, Lee SC, Park KW, Kim WK. Situs anomalies and gastrointestinal abnormalities. J Pediatr Surg. 2006;4 1 (7): 1237 1242.

3. Gandhi DM, Warty PP, Pinto AC, Shetty SV. Perforated DU with dextrocardia and situs inversus. J Postgrad Med. 1986;32:45-46.

4. Cotran RS, Kumar V, Robbins SL. Robbins Pathologic Basis of Disease. 4th ed. Philadelphia, Pa: WB Saunders Co; 1989. 777.

5. Bartoloni L, Blouin JL, Pan Y, Gehrig C, Maiti AK, Scamuffa N, et al. Mutations in the DNAH 11 (axonemal heavy chain dynein type 11) gene cause one form of situs inversus totalis and most likely primary ciliary dyskinesia. Proceedings of the National Academy of Sciences of the United States of America. 2002;99(16):1028210286.

6. Higgins CB. Essentials of Cardiac Radiology and Imaging. Philadelphia, Pa: JB Lippincott Co; 1992,283-331.
7. Jefferson K, Rees S. Clinical Cardiac Radiology. $2^{\text {nd }}$ ed. London, UK: Butterworths; 1980:9-67.

8. Winer-Muram HT. Adult presentation of heterotaxic syndromes and related complexes. J Thorac Imaging. 1995;10(1):43-57.

9. Willis JH: The Heart. $5^{\text {th }}$ ed. New York: McGraw Hill Book Company; 1982;817.

10. Xu BP, Shen KL, Hu YH, Feng XL, Li HM, Lang $Z Q$. Clinical characteristics of primary ciliary dyskinesia in children. Zhonghua Er Ke Za Zhi. 2008;46(8):618-22.

11. Ratani RS, Halter JO, Wang WY, Yang DC. Role of CT in left-sided acute appendicitis: case report. Abdom Imaging. 2002;27:18-19.

12. Deshmukh R, Shah VR. Situs Inversus, Medicolegal Approach. JFMT; 1994;13:33-34.

13. Piryani RM, Piryani RM, Shukla A, Prasad DN, Kohli SC, Shrestha G, et al. Situs inversus with dextrocardia with multiple cardiac lesions in adult: Case Note. Kathmandu University Medical Journal. 2007;5(2):247-249.

14. Heimann T, Sialer A. Acute cholecystitis with situs inversus. NY State J Med. 1979;79:253-254.

15. Ucar AE, Ergul E, Aydin R, Ozgun YM, Korukluoglu B. Left-sided acute appendicitis with situs inversus totalis. Internet J Surg. 2007;1 2:2.

16. Ruben GD, Templeton JM Jr, Ziegier MM. Situs inversus. The complex inducing neonatal intestinal obstruction. J Ped Surg. 1983;18:751 756.

17. Ansari ZA, Skaria J, Gopai MS, Vaish SK, Rai AN. Situs inversus with amoebic liver abscess. J Trop Med Hyg. 1973;76:169-170.

18. Tayeb $M$, Khan FM, Rauf F. Situs inversus totalis with perforated duodenal ulcer: a case report. Journal of Medical Case Reports. 2011 ;5:279. 